\title{
THE LATE DEVELOPMENT HYPOTHESIS VERSUS THE EVIDENCE FROM SENEGAL
}

\section{Maureen Mackintosh*}

Any project which employs people of different political views on research into a subject as contentious as the conditions of industrial labour is bound to generate dispute, even loud dispute. The industrial relations project at the Institute has been no exception, and this paper is there fore solely my own view of the hypothesis in the light of a year's fieldwork in Senegal (one of the three countries, along with Mexico and Sri Lanka, chosen for study).

\section{The Hypothesis}

The Late Development hypothesis ${ }^{1}$ postulates that certain salient features of the 'Japanese Employment System', i.e. the internal organization and ideology of large Japanese firms, will tend to recur in all countries which 'develop late', that is to say, go through a process of capitalist industrialization in the twentieth century. Briefly the features sought in large firms can be summed up as a 'welfare corporatism', characterized by:

low turnover ('low' relative to Europe);

a 'lifetime career structure' assuring workers a steadily rising income over their careers by means of a separation of wage from function; the most original feature of the Japanese system was thought to be its dispensing with the 'equal pay for equal work' principle in wage setting;

as an integral part of such a structure, internal promotion, internal training, and the competitive hiring, at defined 'entry ports', of school leavers and university graduates;

a clear distinction between permanent workers, who benefit from this structure, and temporary workers, who do not;

\footnotetext{
* Maureen Mackintosh is a Research Officer at the Institute of Development Studies.

1 A brief summary is bound to have elements of caricature; for a statement of the hypothesis by its author see the article by R.P. Dore, World Development vol. 2, no. 4/5 April/May 1974, pp. 1-7.
} 
unions chiefly oriented towards bargaining at enterprise or plant level;

a planned personnel structure, with a personnel manager to make and/or implement policy;

substantial welfare benefits provided by the company, and a large wage, or rather total benefits, gap between workers in large firms and wage earners in all other productive sectors of the economy;

an 'enterprise consciousness' or positive identification with the company deliberately fostered by management policy.

The explanations put forward for the expected recurrence of this set of features were based on the diffusion of technology and of organizational forms: the technological gap between the requirements of advanced industry and those of previous forms of work, plus the size of firms, and the fact that each will often have a monopoly of a particular product, means that each firm is forced to do extensive internal training; the aim of the planned career structures is then to retain these trained workers.

The provision of welfare benefits has the same end in view. This reorganization of pay and promotion structures is facilitated by the institution of the personnel manager, and in general by a hierarchical, bureaucratized and planned personnel structure imported from abroad. Given this structure of managerial initiatives, and the differential ability to pay of different firms, unions orientate themselves towards plant or enterprise bargaining, to gain the maximum benefits from each firm, thus moving away from rate-for-the-job principles across firms, and reinforcing the enterprise-centred pattern.

Finally, there are policy implications which boil down to the statement that if this pattern were found to be widespread, then government policy should start realistically from this situation, rather than from the rate-for-the-job, high turnover, flexible unitary labour market assumptions of much labour market analysis in industrialized countries

\section{The Evidence}

To what extent did we find the hypothesized pattern of industrial relations in Senegal? To the extent that we did, does the evidence also support the explanations for this pattern? 
Certain features of industrial organization for which we are looking are embedded in Senegalese labour law, notably a distinction between the status and rights of temporary and of permanent workers, of whom the latter have the right to legal redress against unfair dismissal, and the principle set out in all Collective Agreements of priority of internal promotion over hiring from outside the firm. Both of these, however, are not products of the adaptation of law to Senegalese conditions, but derive from French labour law, imported into French West Africa in the Overseas Labour Code of 1952.

The question, however, is not law but practice. To begin with the question of internal promotion, four different patterns of promotion were visible in the ten firms studied in Senegal in 1973. Firstly, three firms hired effectively only into the lowest grades ${ }^{2}$, thereafter promoting workers as vacancies occurred through supervisor level. These three were all what might be called 'low technology' firms, employing production line techniques requiring on the whole simple skills, with few jobs requiring more than a day or two to learn. Secondly, firms having a more automated technology (such as the groundnut oil firms and the oil refinery) now tend to hire as production workers, above the labourer grades (machine minders and maintenance workers), secondary school leavers with the first level technical qualification, the Certificat d'Aptitude Professionelle (CAP); these entrants can hope to be promoted, should places be available, up to the lower supervisory grades, but with difficulty beyond that. The third pattern is the promotion history of older workers (more than ten years seniority) in these same firms. Many of these men had come into the firms as labourers and had learnt production or maintenance work on the job; they have, while continuing to do essentially the same work, seen their grade gradually increase over the past twenty years, and many in particular had their jobs sharply reclassified when the Collective Agreements were signed in the late 1950s. The fourth pattern is that of, in particular rural, firms which still use a high proportion of temporary or permanent labourers. These firms tend overall to be less organized and planned than the others (and less concerned with the letter of the law), but in general in these firms permanent workers tend

2 Jobs in firms in Senegal are ranked in the Collective Agreements by grade (catégorie) according, in principle at least, to the skill required for the job. With each grade in any industry is associated a base wage. 
to be hired from outside already with some basic skill, with the exception that supervisors of groups of labourers, who then do the daily hiring of their workers, are frequently chosen by management from among the labourers.

What are the explanations of these promotion patterns? The Late Development hypothesis would suggest that the internal promotion occurs where there is a need to establish career patterns to retain trained people. This raises two related issues: turnover, and the extent and methods of training.

Turnover of personnel in industry in Senegal is low by any standards, chiefly because of the large imbalance between the number of people seeking such jobs and the number available. It is very difficult to get a job. However, turnover is higher among more highly skilled staff (engineers and technicians) who are still in short supply, and in demand because of pressure on firms to Africanize these posts, and also among younger workers. Furthermore, more industrial experience does seem to be of positive value in getting another industrial job. This is illustrated by the number of people who succeed in switching between the only two industrial firms left in the inland town of Kaolack. It is also supported by the managers' comments. While the shift described above towards the hiring of blue collar workers from among secondary school leavers with the CAP has occurred as the number of such candidates has increased, managers of these firms expressed no preference for hiring schaol leavers as such. On the contrary they said that they would prefer to hire workers with the qualification plus a few years' experience. Senegalese workers and engineers alike expressed the opinion that any employee offered more money elsewhere would naturally change his job, and while, as a Senegalese engineer who had moved three times pointed out, a 'reputation for instability' would be a bad thing to acquire in such a small business community ${ }^{3}$ there was little trace of a moral as opposed to practical, value being placed upon loyalty to a single employer. ${ }^{4}$

\footnotetext{
3 The total wage and salary earning population in the private sector in Dakar was estimated in 1970 at 45,000 . The group of large employers is small.

4 A contrast is intended with the Japanese view of such loyalty.
} 
The possibility for someone to change jobs depends on the type of skill possessed: the more general the skill and the shorter the supply of it, the better the chances. Because of the small size of the industrial sector in Senegal, skills which in an industrialized country would be transferable become specific. For example, the most skilled production job in the shoe firm is cutting the leather. Since there is no other shoe firm to use this skill, the firm is in no danger of losing these workers, who would be virtually unskilled elsewhere. The majority of production, shop floor jobs in the firms studied either have this kind of skill specificity, or they can be learnt very rapidly. The thesis that firms must create promotion structures for these workers to protect their investment in training seems hard to uphold, especially given labour market conditions. This is much less true of skilled maintenance workers and technicians. Workers who receive lengthy training from a firm may be asked to agree to stay for a given minimum period of years after training.

Even where there is no danger of losing the workers in question, managers may have excellent reasons for instituting internal promotion. One is technical linkages between jobs: if part of the training for one job appears as a by-product of working on another, less-skilled job, then promotion from one job to the other implies a reduction in training costs. Such linkages were found in several of the firms studied. More generally, internal promotion may be an economical method of selecting candidates for a post: for jobs not requiring high levels of technical competence, a manager is not seeking the best candidate in the whole labour market but needs a cheap method of selecting a suitable person. Internal promotion may offer him this, and also allow him to serve other ends, of which the most frequently cited were the maintenance of morale among older workers, the rewarding of merit, ensuring that the more responsible positions were held by people well known to management, and responding to shop floor pressure for such promotion.

All of the foregoing has to be seen in the light of economic conditions in Senegal. The economy is in a state of stagnation and even decline. Real wages seem to have fallen over the last few years, and there is no regular bargaining over the levels of wages, minimum wages for each grade being only occasionally changed at government level. Workers see 
their main hope of a wage rise as promotion within a firm, so that one of the main union activities at the plant level is to press for this kind of increase for individual workers. Unless there are compelling reasons for hiring from the outside, managers may well have more to gain than to lose by giving in to this pressure.

This brings us to the questions of wages and welfare benefits. The hypothesis led us to look for two features in particular: welfare benefits provided by individual firms, and a separation of wage from function to allow for important seniority increments in wages.

Almost all workers in these firms receive additions to their monthly wage packets over and above the base wage for their grade. The only such addition which is a legal obligation on firms is a one per cent increase for each year of seniority up to fifteen years. Beyond this, the relation of wage to seniority depends on the policy of the firm. For example, in the shoe firm, wages are correlated with seniority because of the internal promotion system, but within a grade, the percentage addition to base wages is little affected by seniority, being much more influenced by the type of payment system applied to the job (piece rates or group bonus) and by the type of job done. On the other hand, in the oil refinery where most workers receive some increase in wages each year, wages within for example the seventh grade are more highly correlated with seniority, as they are in firms which have a series of 'steps' between grades, where the more senior workers tend to be higher up on these steps. However, the shift in hiring patterns described above, and the process of Africanization in the last five years, has had a perverse effect on the relation overall between wage and seniority which was summed up by the manager of a peanut oil producing firm: 'The question is simple. The older they are, the less skilled they are, and the less they earn'. This effect is clearly visible in the wage/seniority graph for one of the groundnut oil firms, and it makes it difficult to predict how this relation will look when the new workers have a few years' seniority.

In no firm was there found a separation of wage from function on the Japanese scale. The firm which came closest to such a separation was the clothing firm, because in this firm the relation between grade and job was less closely defined and less contested by the union than in 
other firms, so that management and supervisors had more power to move workers between jobs as they saw fit. In this firm the wage had moved towards being a 'person-related' (as opposed to 'job-related') wage, a fact that fits into the very personalistic style of management of this firm, where hiring was chiefly done through family connections with established workers, and discipline was implemented by a Disciplinary Council of union delegates and supervisors. However, some of the other features for which we were looking were absent from this firm: its personnel policy was not carefully planned, nor was it notably bureaucratized; on the contrary, the daily organization tended to depend on the personnel information carried in the heads of a few supervisors; entry was not competitive but nepotistic, and the firm gave few welfare benefits.

Welfare benefits for workers in addition to regular wages increased noticeably in Senegal during the 1960s and early 1970s. The forms these benefits take are firstly, bonuses: either end of the year, twice yearly (in some firms these now amount to a thirteenth month), or individual bonuses for specific events such as marriage. Secondly, and much the most important quantitatively, there is access to interest-free credit. A very high proportion of Senegalese workers are in debt to their employers, be it for advances on wages in the middle of the payment period, for loans for family events such as baptisms, for hospital expenses, for Muslim festivals such as Tabaski (the loans for which can exceed a month's wages), or for such major expenditures as building a house. In addition to this debt structure, firms must by law offer the services of a nurse, and free consultation with a doctor, plus regular health checks; a few have added to this free vaccination and anti-malarial medication during the wet season, and two have full scale medical insurance for all personnel to which the firm contributes. As for housing, most firms house their Senegalese managers and some, a few technicians. No firm studied provides housing for workers, but a couple are having discussions with unions about the possibility of establishing a Cité Ouvrière. Other benefits found in a few firms include subsidized canteens (still frequently expensive in relation to blue-collar wages) and foodshops and either a premium for the cost of transport, or free firm transport (the latter mainly for shift workers in rather inaccessible firms). 
Iwo questions arise about these benefits. Firstly, why do unions push hard for them? Why do they not push simply for higher wages? And secondly, what are managers' motivations for granting them? To begin with the second question, the firm with the most extensive medical benefits offered a justification in terms of straightforward profitability: by improving the system of preventative checks, and preventative medication, absences had been sharply reduced, and in general productivity benefited from better health care. 'Transport and the discussions about housing were justified on the grounds that it was becoming more and more costly and tiring for workers to get to work, with resultant decreases in efficiency, and increases in lateness. And it must also be true, though this explanation was not of course offered by managers, that workers dependent on a firm not only for wages, but for medical care or housing for the whole family, will be less likely, not so much to leave, but to indulge in the kind of militancy which might be an excuse for sacking. This is illustrated by the fact that welfare benefits are not strongly related to seniority; workers whom firms are genuinely in danger of losing, such as electrical technicians, tend to be given higher benefits on hiring rather than the promise of higher benefits later. Transport, medical insurance or availability of loans generally apply to all permanent workers with some quite small minimum seniority. A few of these benefits have clearly been won by identifiable episodes of militancy of the workers in the firm in question.

Why then do unions in Senegal push for this type of benefit, which is in general decried by unions, for example, in Britain? Firstly, because it is not politically possible for the union to bargain for overall increases at the enterprise level in wage rates: base rates are set at government level, and the union confederation exerts pressure from time to time on the government for such changes. The best the union can do at plant level is to seek for increases for individuals or groups in bonuses or categories. Such increases that can be achieved in this way are uncertain, and at present rapidly eroded by inflation. Medical insurance or housing on the other hand is much more inflation-proof, they directly aid the family as well as the individual worker, and they provide some insurance against the future in a country with no State-provided social security. 
Finally, what structure of trade unionism was found in Senegal? The main tendency which the unions in Senegal carried over from their experience in the colonial era (Senegal gained her independence in 1960) was an orientation towards pressure on the state to implement its demands vis-à-vis private firms. This resulted directly from the pivotal role played by the French colonial state in the conditions of labour: one of the major events in pre-Independence labour history was the series of strikes which led up to the passing of the Overseas Labour Code regulating the conditions of labour in the colonies. Since Independence this orientation towards political action has undergone a mutation: in 1969 the older, combative union federation, the UNTS, was broken up, and a new single confederation, the CNTS, formed. This was dependent on the single governing political party, with several of its leaders holding government posts. As a result of this, and of the pivotal role the state still plays in wage setting, the union now has two orientations. The leaders are in principle spokesmen for the union members at government level, and in fact find themselves very much caught between conflicting pressures when feeling among the working class is strong enough, for example about inflation. Secondly, at plant level, individual union delegates (firms have by law to permit the election of delegates, and all but one of the firms studied had done so) play a role, when they are active, which is a cross between an advocate and a social worker. They spend a large part or their time aiding individual workers in disputes with management, trying to get in dividual jobs reclassified (usually on the grounds that the job has in some way changed), or in trying to see that workers obtain the benefits to which they have a right. They also try to seek improvements in the kind of welfare benefits discussed above. Strikes are in principle illegal (though they do sometimes occur), and there is no overall bargaining over wage levels at the level of the plant. The unions are in effect very weak, and their weakness is reflected in the lack of restrictions in practice on managerial powers over promotion, hiring and the setting of levels of bonuses.

\section{Conclusions}

How then has the Late Development hypothesis stood up to confrontation with Senegal? The main casualty has I think been the structure of explanation which runs from technology, to training, to the need to keep trained people. This may have been a part of the 
explanation of the Japanese structure, since it is most likely to operate in a rapidly expanding economy where trained people are in severely short supply. Senegal, however, is not industrializing rapidly and therefore retaining skilled workers is not a major preoccupation of management.

A more general point is that the structure of the hypothesis, with its emphasis on managerial initiative and on causality at the level of the individual firm, leaves out of account the influence of wider social groups and other social institutions in the explanation of the state of industrial relations. The most evident omission is the role of the state. This is particularly crucial in Senegal because of its colonial history and of the centralized and legalistic form taken by French colonialism (and indeed by French political institutions in general). The importance of law in determining the conditions of industrial labour, the orientation of the trade union movement towards the changing and enforcing of that law, the pivotal role played by the state in wage and price setting, and in the mediation of conflicts, all this was taken over by the Senegalese government from its colonial predecessors. In addition, the post-Independence government has sought to break down the power of the trade union movement, which in the past has disrupted Dakar and threatened the government. The organization and orientation of the Senegalese trades unions, and their current weakness cannot be understood without this background.

Nor can management policy towards wages and welfare be understood without an understanding of government policy on these issues. Basic wages have been officially frozen by the government since the early 1960 s on the public grounds that the industrial workers already form a privileged group. They were raised after the strikes of 1968, and have been raised again recently (1973) in response to outcries against severe inflation. But this raises demands also for higher wages in the public sector, and the government is also seeking other ways of calming the outcry, including encouraging private firms to offer piecemeal bonuses, to set up medical insurance schemes, and to provide cheaper food through co-operative buying schemes in the factories. We have examined above why unions have also sought these benefits.

The political economy of wage setting in semi-industrialized countries is 
very poorly understood at present, but one might say that the firms studied for this project display two different strategies. One is that pursued by the rural firms studied, and to some extent by the clothing firm in Dakar: a high proportion of unskilled or fairly low skilled workers' wages not far above basic wages, or even below minimum wages in one firm, a lack of welfare provision, and a personalistic style of hiring and managing of most of the personnel. At the other extreme are firms with a low or very low proportion of less-skilled workers as a result of mechanization, a rising level of welfare provision, a tendency to provide for workers' families through these welfare benefits, as well as for the workers themselves, a more centralized, bureaucratic and rule-bound style, and a lot more philanthropic rhetoric. The firms which are nearer to the latter than to the former extreme do not necessarily have the most effective internal promotion patterns, nor the closest overall correlation between wage and seniority. It is a mistake, I think, to argue that the emergence of the latter pattern of wage and welfare provision is a result chiefly of technological imperatives, just as it is also a mistake, more often committed by economists, to see mechanization only as the result of increases in wages and welfare benefits (especially in a situation of world inflation). One needs to add, as argued above, government imperatives and policy, and the nature of the trade union movement, and one also needs an understanding of the economic situation of the firms in question: the majority (not all) of the firms studied did not rely to any marked extent on the Senegalese market for the disposal of their goods; they are therefore not involved in any cumulative process of industrialization, based on an internal market, which will tend to raise real wages while also increasing productivity, but are concerned to retain competitivity in export markets based in part on low wages. The large part of capital in the country is foreign, and it should not be assumed that its aims and imperatives are of the same type as those of an indigenous entrepreneurial class in Japanese industrialization.

This brings us to another point. The author of the Late Development hypothesis assumed that Japanese culture had influenced, though not determined, the organization of Japanese industry. This would lead one to seek an answer to the question, to what extent the nature of Senegalese society had influenced the French scheme of industrial relations imported along with French capital. But such adaptations take 
a different form when the managers of the firms are not of the indigenous culture in question. Only in the last four years or so has there begun to be an important number of Senegalese managers of the foreign industrial firms in Senegal, and it will be some years yet before it is seen what adaptations they will eventually bring to the management, though one might hypothesize a more personalistic style, and more 'integrationist' enterprise-oriented rhetoric vis-à-vis the rest of the employees (in part because of the effect of a split which has developed in some firms between Senegalese managers and the technicians who feel underprivileged vis-à-vis the managerial groups). But all this will depend on the economic and political situation in Senegal in the next few years.

In brief then, this project has led us to collect a great deal of detailed information about the internal organization of large firms in three semior little-industrialized countries. The information has certainly demonstrated the need for better understanding of the nature of labour markets and of the social structure of industry in these countries, and has demonstrated the inadequacy of any 'free market, rate-for-the-job' model of the labour markets (an inadequacy which is not, in many people's opinion, limited to the analysis of the labour markets of less industrialized countries). But neither the Japanese model, nor the type of explanation proposed for it has turned out to be adequate to describe or explain Senegalese reality. The research has, as was perhaps inevitable, raised to my mind more questions than it has answered. 